\title{
Skuteczne leczenie ratunkowe inhibitorami kinaz tyrozynowych chorego na B-komórkową ostrą białaczkę limfoblastyczną Filadelfia-dodatnią
}

\section{Effective rescue treatment with tyrosine kinase inhibitors of a patient with B-cell acute lymphoblastic leukemia Philadelpha-positive}

\author{
Ilona Seferyńska ${ }^{1}$, Anna Ejduk ${ }^{1}$, Iwona Solarska ${ }^{2}$, Krzysztof Warzocha $^{1}$ \\ ${ }^{1}$ Klinika Hematologii, Instytut Hematologii i Transfuzjologii, Warszawa \\ ${ }^{2}$ Pracownia Biologii Molekularnej, Instytut Hematologii i Transfuzjologii, Warszawa
}

\begin{abstract}
Streszczenie
Chromosom Filadelfia (Ph) stwierdza sie u 25\% dorostych chorych z rozpoznaniem ostrej biataczki limfoblastycznej (ALL). Przed era inhibitorów kinazy tyrozynowej (TKI) ALL Ph-dodatnia (Ph+) należata do grupy biataczek wysokiego ryzyka. Wprowadzenie TKI do leczenia tych chorych zdecydowanie poprawito rokowanie. Przedstawiono przypadek chorego z rozpoznaniem ALL-Ph(+) ustalonym w marcu 2008 roku, którego leczono chemioterapiq $w$ połaczeniu z imatynibem. Skuteczność leczenia oceniano $w$ ilościowym badaniu reakcji tańcuchowej polimerazy $w$ czasie rzeczywistym; stwierdzenie utraty odpowiedzi molekularnej byto powodem badania obecności mutacji genu BCR-ABL1. Po leczeniu indukujacym $i$ konsolidujacym u chorego uzyskano catkowita remisje (CR) z większq odpowiedziq molekularna, a w czasie leczenia podtrzymujacego - gteboka remisje molekularna. Po zakończeniu podtrzymywania nastapiła utrata remisji molekularnej spowodowana pojawieniem sie mutacji G250E. Zmieniono wię imatynib na dazatynib. Ponownie uzyskano gtebokq remisje molekularnq. Leczenie dazatynibem byto powiktane nawracajacym plynem w optucnej, ale po krótkich przerwach terapie kontynuowano. Po 6 latach leczenia dazatynibem nastapita petnoobjawowa wznowa ALL, zwiazana z pojawieniem sie mutacji F317L genu BCR-ABL1. Zastosowanie chemioterapii i ponatynibu pozwolito na ponowne uzyskanie CR z negatywizacja choroby resztkowej $i$ z gteboka odpowiedzia molekularna. Po prawie 10 latach chory zyje, jest $w$ dobrym stanie i pozostaje $w$ fazie remisji biataczki.
\end{abstract}

Słowa kluczowe: ostra białaczka limfoblastyczna Filadelfia-dodatnia, leczenie, inhibitory kinaz tyrozynowych, imatynib, dazatynib, ponatynib

Hematologia 2018; 9, 1: 73-78

\begin{abstract}
Philadelphia chromosome (Ph) is present in 25\% adult patients suffering due to acute lymphoblastic leukemia (ALL). Before the era of tyrosine kinase inhibitors (TKI) ALL-Ph(+) was regarded as a high-risk form of leukemia. Introduction of combined treatment of TKI and chemotherapy improved patient prognosis. We present a case report of a ALL-Ph(+) patient diagnosed in March 2008, who was treated with chemotherapy and imatinib. The real-time quantitative polymerase chain reaction method, was used to assess treatment outcomes and the loss of molecular response
\end{abstract}

Adres do korespondencji: Ilona Seferyńska, Klinika Hematologii, Instytut Hematologii i Transfuzjologii, ul. Indiry Gandhi 14, 02-776 Warszawa, tel. 223496 334, faks 223496 335, e-mail: iseferynska@wp.pl 
was the reason of testing for the BCR-ABL1 mutation. After induction and consolidation treatment, complete remission (CR) with a major molecular response was achieved, whilst during maintenance therapy a deep molecular response was obtained. Shortly after the maintenance therapy ended there was a loss of molecular response noted due to the appearance of a G250E mutation. Imatinib was stopped and dazatinib was introduced and a deep molecular response was again achieved. Treatment with dazatinib was complicated with recurrent pleural effusion but after short breaks the treatment was then recommenced. After six years of taking dazatinib, fully symptomatic $A L L$ recurred, what was linked with the appearance of the F317L mutation of BCR-ABL1. Following chemotherapy and ponatinib, $C R$ and a deep molecular response was again achieved. After almost ten years the patient is alive in good health and in remission from the leukemia.

Key words: acute lymphoblastic leukemia Philadelphia-positive, treatment, tyrosine kinase inhibitors, imatinib, dasatinib, ponatinib

Hematologia 2018; 9, 1: 73-78

\section{Wprowadzenie}

Chromosom Filadelfia (Ph, Philadelphia) jest najczęściej wykrywaną aberracją chromosomalną u chorych na ostrą białaczkę limfoblastyczną (ALL, acute lymphoblastic leukemia). Występuje u 25\% dorosłych chorych $z$ rozpoznaniem ALL, częściej w starszej grupie pacjentów, u osób powyżej 50 lat - w $50 \%$ przypadków, rzadko u dzieci $(3 \%)[1,2]$. Przed erą inhibitorów kinazy tyrozynowej (TKI, tyrosine kinase inhibitors) ALL Ph-dodatnią $(\mathrm{Ph}+)$ zaliczano do grupy wysokiego ryzyka. Optymalnym leczeniem była polichemioterapia jak $\mathrm{w}$ innych ALL; po uzyskaniu całkowitej remisji (CR) u chorych $\mathrm{w}$ dobrym stanie $z$ dobranym dawcą szpiku zalecano przeszczepienie allogenicznych krwiotwórczych komórek macierzystych (allo-HSCT, allogeneic hematopoietic stem cell transplantation), co istotnie poprawiło wyniki leczenia [1,2]. Istotną poprawę rokowania $w$ tej grupie chorych przyniosło zastosowanie TKI $\mathrm{w}$ połączeniu $\mathrm{z}$ chemioterapią [3-5]. Początkowo stosowano jedynie imatynib, w ostatnich latach wykazano jednak, że TKI drugiej i trzeciej generacji powodują szybszą i głębszą remisję białaczki [6-10]. Obecnie młodszym chorym zaleca się leczenie chemioterapią $z$ TKI, a po uzyskaniu remisji - przeprowadzenie allo-HSCT $[6,8,11]$. Istnieją również wskazania do kontynuacji podawania TKI po przeprowadzeniu allo-HSCT [12]. Chorzy starsi powinni być leczeni TKI z mniej intensywną chemioterapią, a nawet tylko ze steroidami $[8,9,13,14]$. Dzięki TKI rokowanie $\mathrm{u}$ chorych na ALL-Ph $(+)$ zdecydowanie się poprawiło. Ponizej opisano chorego $z$ rozpoznaniem ALL$-\mathrm{Ph}(+)$, ustalonym przed około 10 laty, który jest leczony chemioterapią i TKI pierwszej i kolejnych generacji.

\section{Opis przypadku}

Pięćdziesięciosiedmioletni chory został przyjęty do Instytutu Hematologii i Transfuzjologii (IHT) 17 marca 2008 roku $z$ powodu przypadkowo stwierdzonej małopłytkowości. Przez kilka poprzedzających tygodni mężczyzna uskarżał się na niecharakterystyczne bóle brzucha. Przez kilka lat leczono go z powodu cukrzycy typu 2 - początkowo lekami doustnymi, a następnie insuliną. $\mathrm{W}$ chwili przyjęcia chory był w dobrym stanie, nie zgłaszał bólów brzucha, otyły, bez cech skazy ani infekcji, bez limfadenopatii, powiększona śledziona wystawała około $6 \mathrm{~cm}$ spod luku żebrowego. W morfologii krwi stwierdzono leukocytozę 8,69 G/1, stężenie hemoglobiny $13,7 \mathrm{~g} /$ /dl i liczbę płytek krwi $24 \mathrm{G} / 1$, natomiast w rozmazie krwi obwodowej $14 \%$ blastów, $4 \%$ promielocytów, $4 \%$ mielocytów, $4 \%$ metamielocytów, $3 \%$ pałek, $18 \%$ podzielonych, $1 \%$ kwasochłonnych, $41 \%$ limfocytów, $11 \%$ monocytów oraz 6 erytroblastów. W badaniach biochemicznych zwracała uwagę zwiększona do $930 \mathrm{j} . / 1$ aktywność dehydrogenazy mleczanowej. $\mathrm{W}$ wykonanym badaniu rezonansu magnetycznego jamy brzusznej stwierdzono powiększenie śledziony do $19 \mathrm{~cm}$, poza tym bez limfadenopatii czy innych istotnych patologii. Badanie immunofenotypowe (FACS, fluorescence-activated cell sorting) komórek krwi obwodowej wykazało obecność $20 \%$ komórek o fenotypie $\mathrm{CD} 19+, \mathrm{CD} 10+, \mathrm{CD} 20+, \mathrm{CD} 22+$, CD38-, CD34++, CD45+/-, TdT + z koekspresją linii mieloidalnej CD66+. Wykonano biopsję szpiku, ale nie uzyskano aspiratu szpiku do badań diagnostycznych. W trepanobiopsji stwierdzono proliferację niskozróżnicowanych komórek TdT +, CD20+, CD 43-, MPO-, co odpowiadało rozpoznaniu ALL $z$ komórek B. Badanie molekularne komórek krwi obwodowej wykazało obecność genu hybrydowego 
$B C R-A B L 1$ p190. Na podstawie tych badań rozpoznano ostatecznie ALL typu common BCR-ABL1+.

Po ustaleniu rozpoznania w marcu 2008 roku włączono chemioterapię według zalecanego wówczas przez Polską Grupę ds. Leczenia Białaczek u Dorosłych (PALG, Polish Adult Leukemia Group) schematu PALG 5-2007. Program ten przewiduje przedleczenie prednizonem, pierwszą indukcję epirubicyną, winkrystyną, pegylowaną asparaginazą i prednizonem, następnie drugą indukcję $\mathrm{z}$ zastosowaniem cyklofosfamidu, cytarabiny i merkaptopuryny. Począwszy od drugiej indukcji, według programu zalecano podawanie imatynibu w dawce $600 \mathrm{mg} /$ dobę. Na początku leczenia indukującego $\mathrm{u}$ chorego wykonano nakłucie lędźwiowe $z$ pobraniem płynu mózgowo-rdzeniowego do badań i z profilaktycznym dokanałowym podaniem leków cytostatycznych. Nie stwierdzono cech białaczkowego zajęcia ośrodkowego układu nerwowego (OUN), w późniejszym okresie profilaktykę kontynuowano. Po pierwszej indukcji u chorego nie uzyskano CR, po drugiej indukcji stwierdzono $\mathrm{CR} z$ obecnością $0,5 \%$ choroby resztkowej (MRD, minimal residual disease), którą oceniano metodą FACS. Jakościowe badanie molekularne metodą reakcji łańcuchowej polimerazy poprzedzonej odwrotną transkrypcją (RT-PCR, reverse transcriptase polymerase chain reaction) wykazało obecność genu $B C R-A B L 1$ $\mathrm{w}$ komórkach szpiku. Od drugiej indukcji podawano imatynib w dawce $600 \mathrm{mg} /$ dobę. Nie wykazano zgodności w układzie ludzkich antygenów leukocytarnych (HLA, human lekocyte antigen) między chorym i jego rodzeństwem.

W ramach leczenia konsolidującego remisję od lipca 2008 roku chory otrzymał pierwszy i kolejno drugi cykl chemioterapii, w tym odpowiednio metotreksat, etopozyd i deksametazon oraz cytarabinę, cyklofosfamid i asparaginazę. Stale przyjmował imatynib w dawce $600 \mathrm{mg} /$ dobę. W październiku 2008 roku poddano go profilaktycznemu napromienianiu OUN. W ocenie po leczeniu konsolidującym stwierdzano CR MRD(-), a metodą RQ-PCR w komórkach szpiku - większą remisję molekularną $(0,01 \% B C R-A B L 1)$. Chory nie wyraził zgody na przeszczepienie szpiku od dawcy niespokrewnionego.

W listopadzie 2008 roku rozpoczęto leczenie podtrzymujące $z$ podawaniem cykli chemioterapii zawierających epirubicynę, winkrystynę, kortykosteroidy, merkaptopurynę i metotreksat i przewlekle zalecono imatynib $600 \mathrm{mg} /$ dobę. W badaniach kontrolnych wykonanych w okresie leczenia podtrzymującego stwierdzano utrzymywanie się $\mathrm{CR} \operatorname{MRD}(-)$, a badania molekularne wykonywane metodą ilościową reakcji łańcuchowej polimerazy $\mathrm{w}$ czasie rzeczywistym (RQ-PCR, real-time quantitative polymerase chain reaction) wykazywały głęboką odpowiedź molekularną. Leczenie podtrzymujące zakończono w listopadzie 2010 roku, kontynuowano podawanie imatynibu w monoterapii. Po zakończeniu podtrzymywania obserwowano stopniowy wzrost poziomu transkryptu $B C R-A B L 1$ do $11,2 \%$ i pojawienie się w szpiku choroby resztkowej w ilości 0,8\% w badaniu FACS. Badania molekularne wykazały wówczas obecność mutacji G250E genu $B C R-A B L 1$, która powoduje oporność na imatynib $[15,16]$. W styczniu 2011 roku odstawiono imatynib i włączono dazatynib - początkowo w dawce $140 \mathrm{mg} /$ dobę, a następnie $100 \mathrm{mg} /$ dobę. Po 3 miesiącach, w kwietniu 2011 roku, w szpiku stwierdzono $0,001 \%$ transkryptu $B C R-A B L 1$, a po 12 miesiącach - poniżej $0,001 \% B C R$ - $A B L 1$. Głęboka odpowiedź molekularna utrzymywała się przez następne lata (ryc. 1).

W trakcie wizyty kontrolnej 23 lutego 2012 roku, po roku leczenia dazatynibem, pacjent zgłosił latwe męczenie się i duszność, bez cech zakażenia dróg oddechowych. W badaniu przedmiotowym oraz $\mathrm{w}$ badaniu radiologicznym stwierdzono płyn w lewej opłucnej. Odstawiono dazatynib łącznie na 3 miesiące i włączono furosemid, uzyskując stopniową poprawę samopoczucia chorego i zmniejszenie się ilości płynu w opłucnej. 12 kwietnia 2012 roku wznowiono podawanie dazatynibu w zmniejszonej dawce $80 \mathrm{mg} /$ dobę. W listopadzie 2013 roku w badaniu radiologicznym ponownie stwierdzono obecność płynu w lewej opłucnej. Wstrzymano leczenie dazatynibem przez około 6 tygodni, zlecono u chorego stosowanie furosemidu i prednizonu. Po ustąpieniu cech płynu od 17 grudnia 2013 roku kontynuowano leczenie dazatynibem w dawce $80 \mathrm{mg} /$ dobę. W maju 2014 roku po raz kolejny stwierdzono zwiększenie ilości płynu w lewej opłucnej. Zastosowano leczenie jak poprzednio i po zmniejszeniu się ilości płynu włączono dazatynib w dawce $80 \mathrm{mg} /$ dobę. Kontynuowano leczenie dazatynibem mimo nawracającego płynu w opłucnej, ponieważ utrzymywała się całkowita remisja hematologiczna i cytogenetyczna oraz głęboka molekularna, a płyn szybko ustępował po zastosowanym leczeniu. Poza tym nie było wówczas innej opcji leczenia chorego.

W listopadzie 2015 roku chorego przyjęto do kliniki $z$ powodu nasilonej duszności $z$ towarzyszącymi kaszlem i bólem w klatce piersiowej, jednak bez gorączki. W badaniu przedmiotowym stwierdzono ściszenie szmeru pęcherzykowego po lewej stronie nad całym plucem, a w badaniu 


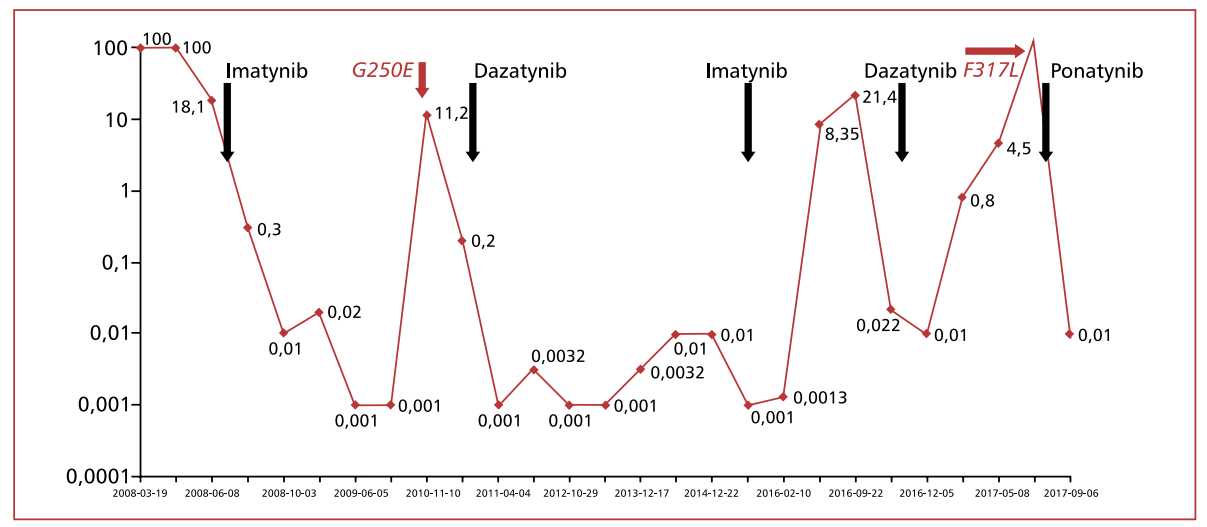

Rycina 1. Odpowiedź molekularna stwierdzana u chorego w okresie od rozpoznania do września 2017 roku. Zaznaczono czas włączenia kolejnych inhibitorów kinaz tyrozynowych oraz wykrycia obecności mutacji w domenie kinazowej BCR-ABL1

Figure 1. Molecular response examined in the patient since the time of diagnosis to September 2017. Times of introduction of particular tyrosine kinase inhibitors and detection of mutations within the BCR-ABL1 kinase domain were marked

radiologicznym klatki piersiowej — dużą ilość płynu po lewej stronie od szczytu płuca do podstawy. Wykonano nakłucie opłucnej, uzyskując $1200 \mathrm{ml}$ krwistego płynu. W badaniu ogólnym był to płyn o charakterze wysiękowym. Posiew płynu był jałowy. Włączono prednison w dawce $40 \mathrm{mg} /$ dobę, $z$ jej następowym zmniejszeniem, leki moczopędne i ciprofloksacynę, a dazatynib odstawiono. W celu rozszerzenia diagnostyki wysięku opłucnowego chorego skierowano do Instytutu Gruźlicy i Chorób Płuc. Tam potwierdzono wysiękowy charakter płynu; nie wykazano etiologii gruźliczej, a w badaniu histopatologicznym nie znaleziono komórek nowotworowych. Na podstawie wykonanych badań rozpoznano wysięk w opłucnej w przebiegu leczenia dazatynibem. Zdecydowano o odstawieniu dazatynibu i zalecono imatynib w dawce $600 \mathrm{mg} /$ dobę. Leczenie imatynibem było dobrze tolerowane. Po 3 miesiącach leczenia nadal stwierdzano głęboką odpowiedź molekularną, ale po 10 miesiącach leczenia nastąpiła utrata odpowiedzi molekularnej ze wzrostem ilości transkryptu $B C R-A B L 1$ do $21,4 \%$. Nie stwierdzono mutacji domeny kinazowej $B C R-A B L 1$. W związku ze znaczącym zwiększeniem ilości transkryptu $B C R-A B L 1$ po roku leczenia imatynibem, $\mathrm{w}$ listopadzie 2016 roku, odstawiono lek i włączono dazatynib w dawce $100 \mathrm{mg} /$ dobę. Już po kilku tygodniach leczenia poziom transkryptu zmniejszył się do $0,01 \%$. Jednak po kilku miesiącach po raz kolejny stwierdzano objawy stopniowego narastania ilości płynu w lewej opłucnej. W czerwcu 2017 roku na krótko odstawiono dazatynib. Ustalono, że optymalnym leczeniem dla chorego byłoby podawanie ponatynibu, nierefundowanego jednak w ramach leczenia $z$ Narodowego Funduszu Zdrowia. Podjęto próby pozyskania leku, zalecając tymczasem kolejny raz leczenie dazatynibem mimo nawracających objawów niepożądanych.

Na początku lipca 2017 roku chory zgłosił się do kliniki z powodu bólów kostno-stawowych, które wymagały intensywnego leczenia przeciwbólowego. W badaniach krwi i szpiku stwierdzono wznowę białaczki. W mielogramie odsetek komórek blastycznych wynosił 20,8\%, w badaniu FACS aspiratu szpiku $-29 \%$, poziom transkryptu $B C R$ -ABL1 natomiast - $121 \%$. Stwierdzono równiez obecność patogennego wariantu mutacji F317L w domenie kinazowej $B C R-A B L 1$, który powoduje oporność na imatynib i dazatynib [15, 16]. Zadecydowano o włączeniu chemioterapii reindukującej według schematu hyper-CVAD (cyklofosfamid, doksorubicyna, winkrystyna, deksametazon). Po leczeniu tym uzyskano CR. 2 sierpnia 2017 roku do leczenia włączono ponatynib w dawce $30 \mathrm{mg} /$ dobę. Po miesiącu wykonano ocenę hematologiczną, stwierdzając CR MRD(-) z poziomem transkryptu $0,01 \%$. Chory kontynuuje monoterapię ponatynibem $z$ dobrym efektem.

Wyniki badań molekularnych chorego wykonanych metodą RQ-PCR od rozpoznania do września 2017 roku przedstawiono na rycinie 1 .

\section{Dyskusja}

Rokowanie u chorych na ALL-Ph(+) zdecydowanie się poprawiło $\mathrm{w}$ erze TKI. $\mathrm{W}$ badaniu 
ALL-0031 dzieci i młodzi pacjenci z ALL-Ph(+) obok chemioterapii otrzymywali TKI w okresie poremisyjnym. Odsetek chorych z 3-letnim czasem wolnym od zdarzeń (EFS, event-free survival) wyniosł $80,5 \%$ (bez procedury allo-HSCT), natomiast $\mathrm{w}$ analogicznej historycznej grupie bez TKI $-35 \%$ [3]. W badaniu grupy MDACC (MD Anderson Cancer Center) u dorosłych 54 chorych zastosowano $\mathrm{w}$ indukcji schemat hyper-CVAD $\mathrm{w}$ połączeniu $\mathrm{z}$ imatynibem, zaś u 14 chorych przeprowadzono allo-HSCT. Trzyletni czas przeżycia całkowitego (OS, overall survival) wyniósł $54 \%$. Wykazano także poprawę przeżycia po allo-HSCT, ale tylko w grupie chorych poniżej 40. roku życia [4]. Lepsze OS i EFS uzyskano po podaniu w ramach leczenia indukującego, obok chemioterapii hyper-CVAD, dazatynibu. Po 2 latach odsetki te wynosiły odpowiednio $64 \%$ i $57 \%$ [18]. Kim i wsp. [7] zastosowali nilotynib $z$ chemioterapią $\mathrm{w}$ pierwszej linii; 2-letnie OS wyniosło $66 \%$, a czas wolny od nawrotu (RFS, relapse-free survival) $-71 \%$ [7]. Chemioterapia hyper-CVAD w skojarzeniu z ponatynibem przyniosła dalszą poprawę wyników leczenia; 2-letnie OS i EFS wyniosły odpowiednio $80 \%$ i $81 \%$ [9, 19].

Opisanego chorego leczono zgodnie $z$ ówczesnymi zaleceniami PALG, czyli chemioterapią i imatynibem. Po zakończeniu fazy konsolidacji stwierdzono CR z negatywizacją MRD badaną metodą FACS, $z$ większą odpowiedzią molekularną ocenioną w badaniu RQ-PCR. Pacjent nie zgodził się na przeszczepienie szpiku od dawcy niespokrewnionego, dlatego poddawano go chemioterapii podtrzymującej $z$ ciągłym podawaniem imatynibu. Po zakończeniu leczenia podtrzymującego nastąpiła utrata odpowiedzi molekularnej ze znacznym wzrostem ilości transkryptu $B C R-A B L 1$. Wykazano wówczas obecność mutacji G250E genu $B C R-A B L 1$ warunkującej oporność na imatynib $[15,20]$. Odstawiono imatynib i włączono dazatynib w monoterapii. Ponownie uzyskano głęboką i długotrwałą odpowiedź molekularną, jednak kilkakrotnie wystąpiło powikłanie leczenia pod postacią narastania płynu w jamie opłucnej. Jest to stosunkowo częste powikłanie leczenia dazatynibem, a mechanizm jego wystąpienia ma charakter immunologiczny. Zaleca się stosowanie przerwy w leczeniu za pomocą TKI oraz podawanie steroidów i leków moczopędnych [21-23]. Takiemu leczeniu poddano chorego. Ponieważ powikłanie leczenia nie było groźne, a inna opcja nie była dostępna, to po ustąpieniu płynu kontynuowano stosowanie dazatynibu. Próba ponownego leczenia imatynibem w 2016 roku zakończyła się niepowodzeniem.
W lipcu 2017 roku wystąpił pełnoobjawowy nawrót ALL. Wykazano wówczas obecność mutacji F317L $\mathrm{w}$ domenie kinazowej $B C R$ - $A B L 1$, która powoduje oporność na imatynib i dazatynib [15, 24, 25]. Zachowana pozostaje wrażliwość komórek białaczkowych na nilotynib i ponatynib. Nilotynib nie jest dostępny ani zarejestrowany do leczenia chorych na ALL. W związku z powyższym pacjent otrzymał chemioterapię reindukującą według schematu hyper-CVAD, a wkrótce po niej włączono ponatynib. Miesiąc po zakończeniu leczenia stwierdzono $\mathrm{CR}$ z głęboką odpowiedzią molekularną.

\section{Podsumowanie}

Chromosom Ph stwierdza się $\mathrm{u} 25 \%$ dorosłych chorych $z$ rozpoznaniem ALL. Wprowadzenie obok chemioterapii TKI, zarówno pierwszej, drugiej i kolejno trzeciej generacji, w leczeniu tych chorych zdecydowanie poprawiło rokowanie [26-28]. Przedstawiony przypadek chorego potwierdza, $\dot{z} \mathrm{e}$ ALL-Ph(+), kiedyś zaliczana do grupy wysokiego ryzyka, dzięki leczeniu chemioterapią i TKI stała sią białaczką o lepszym rokowaniu. Śledzenie stanu remisji białaczki metodami biologii molekularnej umożliwiło wykrycie jej wczesnej wznowy, a stwierdzenie obecności mutacji genu $B C R-A B L 1$ — odpowiednio wczesną zmianę TKI. W erze TKI czas przeżycia chorych na ALL-Ph(+) wydłuża się; $\mathrm{u}$ opisywanego chorego wynosi obecnie prawie 9 lat i 9 miesięcy.

\section{Piśmiennictwo}

1. Pui CH, Relling MV, Downing JR. Acute lymphoblastic leukemia. N Engl J Med. 2004; 350(15): 1535-1548, doi: 10.1056/NEJMra023001, indexed in Pubmed: 15071128.

2. Aricò M, Schrappe M, Hunger SP, et al. Clinical outcome of children with newly diagnosed Philadelphia chromosome-positive acute lymphoblastic leukemia treated between 1995 and 2005. J Clin Oncol. 2010; 28(31): 4755-4761, doi: 10.1200/ /JCO.2010.30.1325, indexed in Pubmed: 20876426.

3. Schultz KR, Bowman WP, Aledo A, et al. Improved early event-free survival with imatinib in Philadelphia chromosome-positive acute lymphoblastic leukemia: a children's oncology group study. J Clin Oncol. 2009; 27(31): 5175-5181, doi: 10.1200/ /JCO.2008.21.2514, indexed in Pubmed: 19805687.

4. Thomas DA, O'Brien SM, Faderl S. Long-term outcome after hyper-CVAD and imatinib (IM) for de novo or minimally treated Philadelphia chromosome-positive acute lymphoblastic leukemia (Ph-ALL). J Clin Oncol. 2018; 28(abstract 6506).

5. Alam A, Qawasmeh K, Kanbar J, et al. Philadelphia positive acute lymphoblastic leukemia $(\mathrm{Ph}+\mathrm{ALL})$, Tawam experience. Blood. 2015; 126: 4867.

6. Liu-Dumlao T, Kantarjian H, Thomas DA, et al. Philadelphia-positive acute lymphoblastic leukemia: current treatment options. 
Curr Oncol Rep. 2012; 14(5): 387-394, doi: 10.1007/s11912-0120247-7, indexed in Pubmed: 22669492.

7. Kim DY, Joo YD, Lim SN, et al. Nilotinib combined with multiagent chemotherapy for newly diagnosed Philadelphia-positive acute lymphoblastic leukemia. Blood. 2015; 126(6): 746-756, doi: 10.1182/blood-2015-03-636548.

8. Chiaretti S, Foà R. Management of adult Ph-positive acute lymphoblastic leukemia. Hematology Am Soc Hematol Educ Program. 2015; 2015: 406-413, doi: 10.1182/asheducation-2015.1.406, indexed in Pubmed: 26637750.

9. Short NJ, Jabbour E. Should treatment of Philadelphia chromosome-positive acute lymphoblastic leukemia be intensive? Intensive treatment is the best treatment for these patients. Clin Adv Hematol Oncol. 2016; 14(11): 892-894, indexed in Pubmed: 27930640.

10. Ravandi F, Kebriaei P. Philadelphia chromosome-positive acute lymphoblastic leukemia. Hematol Oncol Clin North Am. 2009; 23(5): 1043-63, vi, doi: 10.1016/j.hoc.2009.07.007, indexed in Pubmed: 19825452.

11. Ribera JM, García O, Montesinos P, et al. Treatment of young patients with Philadelphia chromosome-positive acute lymphoblastic leukaemia using increased dose of imatinib and deintensified chemotherapy before allogeneic stem cell transplantation. Br J Haematol. 2012; 159(1): 78-81, doi: 10.1111/j.13652141.2012.09240.x, indexed in Pubmed: 22823211.

12. Pfeifer H, Wassmann B, Bethge W, et al. GMALL Study Group. Randomized comparison of prophylactic and minimal residual disease-triggered imatinib after allogeneic stem cell transplantation for BCR-ABL1-positive acute lymphoblastic leukemia. Leukemia. 2013; 27(6): 1254-1262, doi: 10.1038/leu.2012.352, indexed in Pubmed: 23212150.

13. Chalandon $\mathrm{Y}$, Thomas X, Hayette S, et al. Group for Research on Adult Acute Lymphoblastic Leukemia (GRAALL). Randomized study of reduced-intensity chemotherapy combined with imatinib in adults with Ph-positive acute lymphoblastic leukemia. Blood. 2015; 125(24): 3711-3719, doi: 10.1182/blood-2015-02-627935, indexed in Pubmed: 25878120.

14. Foà R, Vitale A, Vignetti M, et al. GIMEMA Acute Leukemia Working Party. Dasatinib as first-line treatment for adult patients with Philadelphia chromosome-positive acute lymphoblastic leukemia. Blood. 2011; 118(25): 6521-6528, doi: 10.1182/ /blood-2011-05-351403, indexed in Pubmed: 21931113.

15. Soverini S, Hochhaus A, Nicolini FE, et al. BCR-ABL kinase domain mutation analysis in chronic myeloid leukemia patients treated with tyrosine kinase inhibitors: recommendations from an expert panel on behalf of European LeukemiaNet. Blood. 2011; 118(5): 1208-1215, doi: 10.1182/blood-2010-12-326405, indexed in Pubmed: 21562040.

16. O'Hare T, Eide CA, Deininger MWN. Bcr-Abl kinase domain mutations, drug resistance, and the road to a cure for chronic myeloid leukemia. Blood. 2007; 110(7): 2242-2249, doi: 10.1182/ /blood-2007-03-066936, indexed in Pubmed: 17496200.

17. Kolenova A, Maloney KW, Hunger SP. Philadelphia chromosomepositive acute lymphoblastic leukemia or chronic myeloid leu- kemia in lymphoid blast crisis. J Pediatr Hematol Oncol. 2016; 38(6): e193-e195, doi: 10.1097/MPH.0000000000000582, indexed in Pubmed: 27164534.

18. Ravandi F, O'Brien S, Thomas D, et al. First report of phase 2 study of dasatinib with hyper-CVAD for the frontline treatment of patients with Philadelphia chromosome-positive $(\mathrm{Ph}+)$ acute lymphoblastic leukemia. Blood. 2010; 116(12): 2070-2077, doi: 10.1182/blood-2009-12-261586, indexed in Pubmed: 20466853.

19. Sora F, Chiusolo P, Laurenti L. Ponatinib before and after allogeneic stem cell transplantation for $\mathrm{Ph}+$ acute lymphoblastic leukemia or lymphoid blast crisis of chronic myelogenous leukemia: a single center experience. J Bone Marrow Res. 2016; 4(2), doi: 10.4172/2329-8820.1000169.

20. Jabbour EJ, Cortes JE, Kantarjian HM. Resistance to tyrosine kinase inhibition therapy for chronic myelogenous leukemia: a clinical perspective and emerging treatment options. Clin Lymphoma Myeloma Leuk. 2013; 13(5): 515-529, doi: 10.1016/j. clml.2013.03.018, indexed in Pubmed: 23890944.

21. Suh KJ, Lee JiY, Shin DY, et al. Analysis of adverse events associated with dasatinib and nilotinib treatments in chronic-phase chronic myeloid leukemia patients outside clinical trials. Int J Hematol. 2017; 106(2): 229-239, doi: 10.1007/s12185-017-2225-1, indexed in Pubmed: 28378056.

22. Jabbour E, Deininger M, Hochhaus A. Management of adverse events associated with tyrosine kinase inhibitors in the treatment of chronic myeloid leukemia. Leukemia. 2011; 25(2): 201-210, doi: 10.1038/leu.2010.215, indexed in Pubmed: 20861918.

23. Cortes JE, Jimenez CA, Mauro MJ, et al. Pleural effusion in dasatinib-treated patients with chronic myeloid leukemia in chronic phase: identification and management. Clin Lymphoma Myeloma Leuk. 2017; 17(2): 78-82, doi: 10.1016/j.clml.2016.09.012, indexed in Pubmed: 28082112.

24. Eskazan AE, Soysal T, Erbilgin Y, et al. Chronic myeloid leukemia patients with F317L BCR-ABL kinase domain mutation are resistant to dasatinib: is that true for all the patients? Leuk Res. 2011; 35(9): e145-e146, doi: 10.1016/j.leukres.2011.04.025, indexed in Pubmed: 21605905.

25. Jabbour E, Kantarjian HM, Jones D, et al. Characteristics and outcome of chronic myeloid leukemia patients with F317L BCR-ABL kinase domain mutation after therapy with tyrosine kinase inhibitors. Blood. 2008; 112(13): 4839-4842, doi: 10.1182/ /blood-2008-04-149948, indexed in Pubmed: 18818391.

26. Eden T. Acute lymphoblastic leukaemia. Oxford Medicine Online. 2010, doi: 10.1093/med/9780199204854.003.220303.

27. NCCN clinical practice guidelines in oncology ( $\mathrm{NCCN}$ Guidelines) acute lymphoblastic leukemia. NCCN guidelines version 4.2017.

28. Sacha T. Ponatynib w leczeniu przewlekłej białaczki szpikowej i ostrej białaczki limfoblastycznej z chromosomem Filadelfia. Acta Haematol Pol. 2016; 47(2): 128-138, doi: 10.1016/j. achaem.2016.04.002. 